\title{
Future prevention and treatment of chronic hepatitis B infection
}

Wai-Kay Seto ${ }^{1}$ MRCP, James Fung ${ }^{1}$ MD, Man-Fung Yuen ${ }^{1,2}$ MD, Ching-Lung Lai ${ }^{1,2}$ MD

'Department of Medicine, the University of Hong Kong, Queen Mary Hospital, Hong Kong

${ }^{2}$ State Key Laboratory for Liver Research, University of Hong Kong, Queen Mary Hospital, Hong Kong

Keywords: vaccination; HELIPSAV; besifovir; REP 9AC; interferon lambda; FG-3019

Correspondence and Reprint request:

Prof. Ching-Lung Lai, Department of Medicine, The University of Hong Kong Queen Mary Hospital, Pokfulam Road, Hong Kong

E mail: hrmelcl@hkucc.hku.hk

Fax: 85228162863

Tel: 85222554477 
The authors declare they have participated in the preparation of the manuscript and have seen and approved the final version.

\section{Disclosure statement}

WK Seto is a clinical investigator for trials under LG Life Science and Bristol-Myers Squibb. J Fung is an invited speaker for Bristol-Myers Squibb. MF Yuen is a clinical investigator for trials under LG Life Science, FibroGen and Bristol-Myers Squibb, and is an invited speaker for Bristol-Myers Squibb. CL Lai is a clinical investigator for trials under LG Life Science and FibroGen, and is an invited speaker for Bristol-Myers Squibb.

Role of the funding source

All authors have nothing to disclose

(Word count: 4076) 


\section{Abstract}

Vaccination for hepatitis B virus (HBV) infection and treatment for chronic hepatitis $B(\mathrm{CHB})$, while effective for primary prevention and control of the disease, still have their limitations. Global coverage of HBV immunization needs improvement. Several patient populations are noted to have suboptimal seroprotective rates after HBV vaccination. There are currently several potential new vaccines undergoing animal and human studies, most notably vaccines containing immunostimulatory DNA sequences. Long-term nucleoside analogue therapy is necessary in achieving permanent virologic suppression. Potential new treatments explore new mechanisms of action, including the inhibition of hepatitis B surface antigen release, targeting anti-fibrotic mechanism, and immunomodulation through novel interferons and therapeutic vaccines. The clinical application of potential new vaccines and therapies would enhance the prevention of $\mathrm{HBV}$ infection and treatment of $\mathrm{CHB}$.

(126 words) 


\section{Introduction}

It is estimated that 2 billion people worldwide have been exposed to the hepatitis $B$ virus (HBV) (1). Four hundred million patients are infected with chronic hepatitis $B$ (CHB), with an estimated 600,000 deaths annually from its associated complications (2). The last few decades has witnessed remarkable progress in the treatment and prevention of $\mathrm{CHB}$. The introduction of universal HBV vaccination has markedly reduced the prevalence of HBV infection $(3,4)$. Recent years have also seen a drastic increase in therapeutic options in CHB. Permanent virologic suppression, and sometimes even hepatitis B surface antigen ( $\mathrm{HBsAg}$ ) seroclearance, can now be achieved (5). Nevertheless, both vaccination and treatment in CHB still have their limitations. Future potential improvements in vaccination and therapy will be discussed thoroughly in this review.

\section{Vaccination - current standards and limitations}

The first HBV vaccines being introduced in 1982 were plasma-derived, and with improvements in recombinant DNA technology, were gradually replaced by recombinant-based vaccines (6). Serum antibody to the hepatitis B surface antigen (anti-HBs) of $\geq 10 \mathrm{mlU} / \mathrm{mL}$ is defined as a protective level. Currently, 162 countries have already implemented universal HBV vaccination programs (7), although a World Health Organization report in 2006 found actual implementation of vaccination among newborns to be only 26 to $36 \%$ (8).

A study in Taiwan by $\mathrm{Ni}$ et al followed up 18,779 vaccinated newborns for 20 years. They found the rate of HBsAg positivity to be only $1.2 \%$ (4). Other Taiwanese 
studies established the efficacy of universal vaccination in reducing fulminant hepatic failure $(9,10)$ and hepatocellular carcinoma (HCC) (11). Studies in Hong Kong also confirmed the efficacy of both plasma-derived and recombinant-based vaccines without booster doses up to 22 years of follow-up, with highly effective anamnestic responses in patients with low anti-HBs titers i.e. a significant increase in anti-HBs titers indicating exposure to HBV without development of HBV infection. (12-15). Studies in Italy and Alaska, regions with an intermediate endemicity of $\mathrm{CHB}$, also found universal HBV vaccination to achieve a similar efficacy $(16,17)$. A meta-analysis of 42 separate cohorts found the cumulative incidence of HBV breakthrough infection in immunocompetent subjects to be $0.7 \%$ (18). The occurrence of vaccine-escape HBV mutants, initially a concern when discovered (19), was noted to be of limited prevalence, probably due to the replicative weakness of the mutant virus $(20,21)$.

Factors associated with failure of the HBV vaccine are listed in Table 1. Identified risk factors for vaccine failure among newborns include hepatitis $\mathrm{B}$ e antigen ( $\mathrm{HBeAg})$ positivity and a high viral load in HBsAg-positive mothers $(4,22)$. In addition, current HBV vaccines are noted to be suboptimal among adult populations with impaired immunity. Rates of seroprotection are lower with increasing age, obesity, smoking, diabetes and renal disease (23-25). In patients with end-stage renal disease (ESRD) receiving hemodialysis, response rates could be as low as 50 to $70 \%(26,27)$, especially among patients with co-existing hepatitis $C$ infection (28) and poor nutritional status (29). Outbreaks of HBV infection were still reported among hemodialysis units in developed countries (30). The response rates among patients with human immunodeficiency virus (HIV) infection are also lower (31, 32); using additional booster 
doses and increasing the vaccine dose in such subjects only attained 1-year response rates of $58.8 \%$ to $63.0 \%(33,34)$. Other patient groups prone to vaccine failure include chronic alcoholics with overt liver disease (35) and recipients of liver (36) and renal (37) transplant.

Hence, while universal HBV vaccination has a profound impact in the prevention of HBV transmission, there are two areas needing improvement: increasing global vaccination coverage, and enhancing response rates among the suboptimal response groups mentioned above. The first aspect requires international collaborative efforts by governments of endemic countries, the World Health Organization and different nonprofit organizations. The following sections will concentrate on the second aspect.

\section{Enhancing vaccination response}

A recent study analyzed data from 2,356 children born to HBsAg-positive mothers in Taiwan found children born to HBeAg-positive mothers to have a higher prevalence of $\mathrm{HBsAg}$-positivity compared to children born to $\mathrm{HBeAg}$-negative mothers $(9.26 \%$ and $0.23 \%$ respectively, $p<0.001)$ (22). The authors suggested utilizing serum $\mathrm{HBeAg}$ in addition to $\mathrm{HBsAg}$ as screening tools to identify vaccinated children at high risk of developing CHB. Prospective trials would be needed to justify its costeffectiveness.

Nucleoside analogue therapy in $\mathrm{HBeAg}$-positive mothers has been shown to reduce perinatal transmission. In two recent studies, telbivudine treatment in $\mathrm{HBeAg}$ positive mothers, starting in the second or third trimester, was associated with a significant reduction in rates of perinatal transmission up to 28 weeks after delivery ( 38 , 
39). There are also studies showing the administration of hepatitis $B$ immunoglobulin (HBIG) to either HBsAg-positive mothers (40) or newborns (two-dose injections) (41) is able to improve vaccine responsiveness. Long-term follow-up results of the above studies would be needed to ascertain the efficacy of both antenatal nucleoside analogue therapy and perinatal HBIG administration.

Various strategies have also been employed to improve vaccine responsiveness in high-risk adults (Table 1). Intradermal vaccination, when given to patients with ESRD, is able to achieve higher rates of anti-HBs positivity $(42,43)$, although an improved response was not reproduced among patients with HIV infection $(44,45)$. Increasing the vaccine dosage among patients with ESRD can also improve vaccine response (46). Other suggested approaches include improving the vaccine adjuvant formula $(47,48)$, using plasmid DNA vaccines that encode $\operatorname{HBsAg}(49,50)$, and administrating $\mathrm{HBsAg}$ pulsed blood dendritic cells (51). Many such suggested methods are still undergoing in animal studies.

There is currently one promising vaccine that has already undergone multiple clinical trials - the hepatitis B surface antigen-1018 ISS adjuvant containing vaccine (HELIPSAV).

\section{Hepatitis B surface antigen-1018 ISS adjuvant containing vaccine (HELIPSAV)}

Immunostimulatory DNA sequences (ISS) are unmethylated cytosine phosphoguanosine $(\mathrm{CpG}$ ) motifs that are found in various viruses, including HBV, but are rare in mammalian cells (52). These CpG motifs are recognized by toll-like receptor 9, resulting in the preferential activation of type 1 ( $\mathrm{TH} 1)$ immune response that 
subsequently amplifies adaptive immune responses (53). Several cytokines, including interleukin-12 and type I interferon (IFN) secreted by dendritic cells, are involved in this immune process (54). As a result, synthetic ISS are attractive vaccine adjuvants that stimulate specific pathways critical to immune response regulation, resulting in minimal toxicity (55).

The ISS contained in HELIPSAV is a 22-mer phosphorothioate oligonucleotide, which is mixed with $20 \mu \mathrm{g}$ of yeast (56). Excellent protective anti-HBs titers and good tolerability were noted in initials phase I studies (57). This was followed by a phase II comparative study using a licensed recombinant HBV vaccine among 99 healthy subjects aged 18 to 28 years. A greater proportion of HELIPSAV-treated recipients had a seroprotective anti-HBs levels at week 28 after when compared to those given recombinant HBV vaccine $(100 \%$ and $64 \%$ respectively, $\mathrm{p}<0.001)$. HELIPSAV-treated group also had higher geometric mean titers than the recombinant vaccination group (2,074 versus $32 \mathrm{mlU} / \mathrm{mL})(58)$.

The phase III results of HELIPSAV have been recently published (59). The first study, involving 2,415 healthy subjects aged 11 to 55 compared two doses of HELIPSAV versus three doses of recombinant HBV vaccination. HELIPSAV was able to achieve a higher seroprotective rates when compared to recombinant vaccine at the primary immunogenicity endpoint $(95.1 \%$ and $81.1 \%$ respectively). Another phase III study investigated the efficacy of HELIPSAV in $\underline{420 \text { healthy subjects aged } 40 \text { to } 70}$ years and seronegative to $\mathrm{HBsAg}$, anti-HBs and antibody to the hepatitis B core antigen (anti-HBc) (60). The seroprotective rate of HELIPSAV was significantly higher at week 50 when compared to recombinant vaccine (100\% versus $68.6 \%$ ). A third study 
involving 2,449 participants aged 40-70 found HELIPSAV to achieve a seroprotective rates of $94.6 \%, 94.7 \%$ and $95.6 \%$ in males, obese subjects and smokers respectively. The seroprotective rates in the recombinant vaccine group among these three subject populations were only $67.8 \%, 65.4 \%$ and $65.3 \%$ respectively (61). In all studies, HELIPSAV was well-tolerated with similar safety profiles when compared to the recombinant vaccine.

The report of a case of Wegener's granulomatosis 171 days after the second dose of HELIPSAV (59) led to the vaccine being put on hold by the United States Food and Drug Administration in 2008 (62). However, clinical hold on HELIPSAV has been lifted since September 2009 after the provision of additional safety data by the manufacturing pharmaceutical company.

\section{Other vaccine adjuvants}

Other clinical trials in human subjects are summarized in Table 2. CPG 7909 is another CpG motif-based HBV vaccine adjuvant that has been found effective in phase I studies (63) and phase II studies involving HIV-infected subjects (64). Vaccine adjuvants systems that stimulate both cellular and antibody immune responses have been recently proven to be effective against malaria (65), and a similar system known as AS02, using monophosphoryl lipid A and Quillaja saponaria as vaccine adjuvants is also effective against HBV (66), including in patients with renal insufficiency (67). There are also oral (49) and intranasal (68) HBV vaccines undergoing clinical evaluation. 
Information on HBV vaccines still in the phase of animal studies has been described in detail elsewhere $(69,70)$. Therapeutic vaccines aimed at $\mathrm{CHB}$ treatment would be described in a subsequent section.

\section{Treatment of chronic hepatitis B - current standards}

Treatment of $\mathrm{CHB}$ has been revolutionized in the last two decades. Sustained and profound virologic suppression is now possible with continuous nucleoside analogue therapy $(71,72)$. These can result in a reduction in the incidence of cirrhotic complications and $\operatorname{HCC}(73,74)$, as well as in reversing biopsy-proven cirrhosis $(75)$. Certain CHB populations also respond satisfactorily to pegylated IFN therapy (76).

Despite the favorable responses achieved with current available therapy, there are definitely aspects for improvement. Pegylated IFN therapy is still limited by its suboptimal response rate in certain CHB populations and its side-effect profile (77). Concerning nucleoside analogue therapy, HBsAg seroclearance, the ultimate treatment endpoint, is rarely seen (78). A prolonged treatment duration with potent nucleoside analogue therapy is needed in order to achieve histologic regression of fibrosis or cirrhosis (75). The reduction in the incidence of HCC, though significant, is not absolute (79). Lastly, no treatment can totally eradicate HBV in infected individuals. This ultimate

objective may not be achievable since HBV forms highly stable covalently closed circular DNA (cccDNA) in the hepatocyte nuclei, as well as integrates into the host genome from the early stage of the infection.

An exhaustive summary of novel anti-HBV drugs undergoing human and animal trials can be found elsewhere (80). This review concentrates on therapies with the 
potential to be approved for widespread use in the foreseeable future. These include novel nucleoside analogues, HBsAg release inhibitors, novel IFNs, anti-fibrotic agents and therapeutic vaccines (Table 3).

\section{Novel reverse transcriptase inhibitors}

Given the established efficacy of nucleos(t)ide analogues in controlling $\mathrm{CHB}$ infection, there are several novel drugs that inhibit the reverse transcriptase involved in HBV DNA replication for both wild-type and drug-resistant HBV. These include besifovir and lagociclovir.

Besifovir (LB-80380)

Besifovir is an acyclic nucleotide phosphonate with its chemical structure similar to that of adefovir and tenofovir (81). It is a prodrug which is converted to LB-80331 through deacetylation in both the liver and intestine, then further oxidized to LB-80317, the active metabolite with antiviral effect towards HBV (Figure 1). LB-80317, unlike the prodrugs of adefovir and tenofovir, uses guanine instead of adenine as its base moiety, which contributes to an improved drug efficacy due to the lower intracellular concentrations of potentially competing guanine nucleotides compared to adenine nucleotides (82). Preclinical studies have found besifovir to show potent antiviral efficacy against both wild-type and drug-resistant HBV, with little reduction in mitochondrial DNA or lactic acid accumulation. Animal studies also found besifovir, when used in a similar dose as adefovir, to be 45 times less nephrotoxic (81). 
A randomized placebo-controlled phase lb dose escalation study of besifovir was performed in 29 Asian HBeAg-positive CHB patients for 4 weeks with a 12-week follow-up period (83). The maximum median HBV DNA reductions were 3.05, 4.20, 3.67 and $3.68 \log$ copies $/ \mathrm{mL}$ for doses 30, 60, 120 and $240 \mathrm{mg}$ respectively. All reductions in viral loads were significantly greater when compared to placebo $(p=$ $0.011)$.

A phase II, open-label, multicenter, dose escalation study was performed in 65 lamivudine-resistant $\mathrm{HBeAg-positive} \mathrm{CHB}$ patients (84). Besifovir was given together with lamivudine for 4 weeks, then followed by 8 weeks of besifovir monotherapy, subsequently followed by 24 weeks of adefovir. The mean HBV DNA reductions from baseline were $2.81,3.21,3.92,4.16$ and 4.00 log copies $/ \mathrm{mL}$ for doses $30,60,90,150$ and $240 \mathrm{mg}$ respectively. The degree of HBV DNA suppression at week 12 was dosedependent $(p<0.001)$. The drug was also well-tolerated with no drug-related adverse events reported. Another phase Ilb multicenter study compared the efficacy and safety of besifovir with entecavir up to 48 weeks $(85,86)$. One hundred and fifteen CHB patients were randomized in a ratio of $1: 1: 1$ to receive either besifovir $90 \mathrm{mg}$, besifovir $150 \mathrm{mg}$ or entecavir $0.5 \mathrm{mg}$ daily. After 48 weeks, besifovir $90 \mathrm{mg}$ and $150 \mathrm{mg}$ were found to have similar rates of virologic suppression when compared with entecavir $\underline{(67.7 \%, 81.8 \% \text { and } 80.0 \% \text { respectively achieving HBV DNA }<60 \mathrm{lU} / \mathrm{mL}, \mathrm{p}>0.05)}$. Rates of $\mathrm{HBeAg}$ seroconversion were also comparable $(21.1 \%, 16.7 \%$ and $14.3 \%$ respectively, $p>0.05$ ). Full sequencing of the HBV polymerase region during follow-up did not detect any resistant mutations. Both doses of besifovir were significantly 
associated with the lowering of L-carnitine levels, which were normalized in all patients with carnitine replacement. No other drug-related adverse events were reported.

With its high potency, besifovir may find its place in the future as a third first-line agent, both for treatment-naïve as well as for lamivudine-resistant patients.

\section{Lagociclovir}

Lagociclovir valactate (also known as MIV-210) is a prodrug of 3'-fluoro-2', 3'dideoxyguanosine (FLG). Animal studies have found FLG to be a potent inhibitor of hepadnavirueses, which includes HBV (87), and is active against lamivudine-, adefovirand entecavir-resistant HBV (88).

A woodchuck model involving different doses of lagociclovir found serum HBV DNA to decrease by more than $7 \log$ after 10 weeks of therapy. There was also a 2 log decrease in intrahepatic covalently closed circular DNA (cccDNA). The reduction in HBV DNA, when compared to previous woodchuck models, was comparable to entecavir and better than lamivudine or adefovir (89). Phase I and II clinical studies are currently ongoing in Europe and Asia (80).

\section{HBsAg release inhibitors}

All currently available oral anti-HBV medication are nucleos(t)ide analogues, which target the activity of reverse transcriptase in viral replication. There has been research aimed at developing novel drugs targeting other areas in the biology of HBV. The inhibition of HBsAg release is one such potential target, especially since the 
therapeutic reduction of serum $\mathrm{HBsAg}$ is associated with a corresponding decline in intrahepatic cccDNA (90).

The HepG2 and HepA2 cell lines transfected by HBV have been applied as in vitro models in evaluating the efficacy of novel anti-HBV drugs. A study reported artesunate-containing herbal extracts were able to effectively inhibit serum HBsAg release in HepG2 cells (91). Serum HBsAg production was also similarly suppressed by pyranocoumarin analogues in HepA2 cells based on extracts isolated from the medicinal plant Clausena excavate (92). An aromatically substituted tetrahydrotetrazolo-(1, 5-a)-pyrimidine known as HBF-0259 was able to suppress HBsAg production in HepG2 cells without affecting HBeAg or HBV DNA synthesis (93). A chemically improved version of HBF-0259 was able to achieve potent HBsAg inhibition in HBV-transgenic mice and was effective against both wild-type and drug-resistant HBV. No signs of toxicity through serum chemistry analysis were noted (94).

REP 9AC

REP 9AC is a nucleic acid-based amphipathic polymer, which belongs to a new class of antiviral compounds based on the sequence-independent activity of phosphorothioated oligonucleotides. Similar amphipathic molecules have been found to exhibit potent antiviral activity against human immunodeficiency virus (HIV) (95), hepatitis C virus (96) and cytomegalovirus (97). REP 9AC facilities innate immunity against HBV by inhibiting release of subviral particles, including HBsAg, from infected hepatocytes. Both $\mathrm{HBsAg}$ and $\mathrm{HBeAg}$ have been reported to abrogate the toll-like 
receptor induced innate response against HBV, resulting in the persistence of HBV infection (98).

Phase $1 /$ II studies of REP 9AC are currently ongoing. Interim reports found the intravenous infusion of REP $9 \mathrm{AC}$ resulted in $>99.5 \%$ reduction in $\mathrm{HBsAg}$ in 7 of 8 patients within 7 days to 32 weeks of treatment, with a corresponding reduction in serum HBV DNA also noted. After stopping therapy, 3 patients maintained serum HBV DNA $<500$ copies $/ \mathrm{mL}$ and $\mathrm{HBsAg}<10 \mathrm{IU} / \mathrm{mL}$, while the other patients had $>90 \%$ reduction in HBsAg and 2 to 7 log reductions in $\operatorname{HBV}$ DNA $(99,100)$. These preliminary results indicate HBsAg release inhibitor could become an important new tool in the control of $\mathrm{CHB}$ in the future.

\section{Interferon-lambda (IFN- $\lambda$ )}

IFN-based therapy in $\mathrm{CHB}$, while offering the advantage of a finite duration of therapy and the slightly higher rate of $\mathrm{HBsAg}$ seroclearance, is associated with high rates of virologic rebound after treatment cessation and an unfavorable side-effect profile (101). The multiple side-effects seen are related to the abundant IFN- $\alpha$ receptor distributed throughout the whole human body. IFN- $\lambda$ (Figure 2), discovered in 2003 (102), induces antiviral response via a pathway similar to IFN- $\alpha$ and $-\beta$. IFN- $\lambda$ receptors, although expressed in high amounts in hepatocytes(103), are not found in other human cells including fibroblasts, monocytes, adipocytes or primary central nervous system cells, and is thus associated with less systemic side-effects when administered (104, 105). 
IFN- $\lambda$, despite its molecular difference, shares similar biological characteristics with IFN- $\alpha$ and $-\beta$. The stimulation of IFN- $\lambda$, similar to IFN- $\alpha$ and $-\beta$, involves toll-like receptors $(102,106)$. All three IFNs activate IFN-stimulated regulatory factor 3 and induces the expression of genes containing IFN-stimulated response elements (106). Nevertheless, IFN- $\lambda$ does not bind to the IFN- $\alpha$ receptor complex, but triggers its cellular activity through a receptor consisting of two subunits: an interleukin-10 receptor and an IFN- $\lambda$ receptor 1 (107).

IFN- $\alpha$ inhibits HBV replication by preventing the assembly of viral RNAcontaining capsids in the cytoplasm (108). IFN- $\lambda$ operates through a similar molecular mechanism as demonstrated by a study using murine hepatocytes (107). Subsequent studies using human hepatocytes also demonstrated a similar efficacy in inhibiting HBV replication $(109,110)$.

Phase I and II studies in CHB patients are currently ongoing. From published data on pegylated IFN- $\lambda$ in chonic hepatitis $C$ patients, IFN- $\lambda$ was well-tolerated with minimal adverse effects (111). The efficacy of IFN- $\lambda$ was reduced in chronic hepatitis $C$ patients with prior IFN- $\alpha$ treatment (105) Its effect against HBV will have to await the results of current clinical trials.

\section{FG-3019 - novel antifibrotic agent}

Hepatic fibrogenesis is a common pathway of liver damage seen in many chronic liver diseases, including $\mathrm{CHB}$. The development of anti-fibrotic agents aimed at regressing liver fibrosis has thus aroused great interest. Fibrogenic mechanisms are 
dependent on the interplay of many pro- and anti-fibrotic cytokines, of which transforming growth factor beta (TGF- $\beta$ ) has been viewed as the "master" cytokine crucial for the advancement of fibrosis (112). Important regulators of these cytokines are the connective tissue growth factors (CTGFs). Initially discovered in 1991 in the conditioned medium of human umbilical vein endothelial cells (113), CTGF consists of four domains (Figure 3), and up-regulates the majority of pro-fibrotic cytokines, including TGF- $\beta$, hence promoting hepatic fibrosis (114). CTGF expression has been noted in hepatic stellate cells (HSCs), the main producers of extracellular matrix proteins related to fibrosis, in both experimental models and human patients $(115,116)$. Hepatocytes infected by HBV are also noted to have increased CTGF and TGF- $\beta$ up-regulation (117). Fibrogenesis is likely triggered by the $\mathrm{X}$ protein of HBV, with human and rat HSCs exposed to the $\mathrm{X}$ protein showing an increased expression of CTGF, TGF-beta and other fibrogenic cytokines (118).

FG-3019 is an anti-CTGF monoclonal antibody that is designed to inhibit to inhibit TGF- $\beta$ related fibrosis. The second domain of CTGF, which is homologous to the von Willebrand factor type C repeat, is the binding site of FG-301 (Figure 3). FG-3019 has the potential to be used in multiple disease entities in which fibrogenesis is a major pathophysiological element, including pulmonary fibrosis, pancreatic cancer, kidney disease and liver fibrosis. Animal studies have found FG-3019 able to improve histologic signs of liver fibrosis by reducing the accumulation of extracellular matrix in the liver and reduce the number of activated HSCs (119). Hydroxyproline:proline (Hyp:Pro) ratios, which quantitatively scores organ fibrosis by measuring the collagen content relative to total organ protein, are increased by the co-administration of CTGF 
and TG-F $\beta$. Hyp:Pro ratios are however significantly reduced in the liver through the administration of FG-3019 (120).

Phase I and II studies are currently ongoing in South East Asia, investigating the effect of FG-3019 or placebo with entecavir in CHB. FG-3019 is well-tolerated with no drug-related adverse effects, as shown in clinical trials involving pancreatic cancer and diabetic kidney disease $(121,122)$.

\section{Therapeutic vaccines}

A key element in the chronicity of HBV infection is the weakened innate immunity system resulting in the failure of viral clearance. Hepatocytes infected by HBV inhibit CD8 $\mathrm{T}$ cells, leading to the impairment of $\mathrm{T}$-cell function and reduction of anti-viral cytokines (e.g. IFN- $y$ and tumor necrosis factor- $\alpha$ ) (123). Therapeutic vaccination is thus a potential strategy which could theoretically eradicate HBV by strengthening the patient's immune response (124), although the results of such trials have not been satisfactory.

A double-blind placebo controlled phase II trial used a therapeutic vaccine containing $\mathrm{HBsAg}$-anti-HBs immune complexes in $\mathrm{HBeAg}$-positive $\mathrm{CHB}$. Although increased rates of $\mathrm{HBeAg}$ seroconversion were seen in the therapeutic vaccine arm, there was no difference in the rates of virologic suppression (125). Moderate levels of serum HBV DNA and HBsAg levels were still seen 24 weeks post-treatment (126). DNA vaccines are gaining in popularity given their ability to induce both humoral and cellular immune responses. Two phase I studies investigated therapeutic plasmid DNA vaccines based on recombinant $\mathrm{HBsAg}$ proteins, which, although well-tolerated and 
immunologically effective, did not result in significant HBV DNA suppression $(127,128)$. Another study found combining a DNA vaccine containing recombinant interleukin-12 with lamivudine did not improve rates of virologic suppression (129). DNA vaccines also fail to maintain virologic remission after cessation of nucleoside analogue therapy (130).

One promising therapeutic vaccine currently undergoing clinical trials is DV-601. This vaccine comprises of recombinant $\mathrm{HBsAg}$ and hepatitis $\mathrm{B}$ core antigen $(\mathrm{HBcAg})$, and is engineered to stimulate a broad spectrum of T cells. In a phase I dose-escalation study, 14 CHB patients were started on concurrent entecavir and DV-601. A preliminary analysis showed all patients to have substantial reductions in both serum HBV DNA and HBsAg titers; HBeAg titers were also reduced in $\mathrm{HBeAg}$-positive patients. Anti-HBs and antibody to the hepatitis B e antigen (anti-HBe) developed in higher dose groups. The vaccine was also well-tolerated (131).

The problem with therapeutic vaccines is that most CHB patients, especially those from Asia, Africa and certain Mediterranean countries, have been exposed to the virus since early childhood when the immune system is not yet fully matured. These carriers have also been exposed to large amounts of HBsAg for long periods of time. With the virus forming cccDNA inside the hepatocyte nuclei as well as viral integration into the host genome, $\mathrm{CHB}$ patients might not mount a satisfactory immune response to therapeutic vaccination.

\section{Future directions}

$\mathrm{CHB}$ is now both preventable and treatable due to the remarkable advances achieved in the last three decades. Yet, eliminating and eradicating HBV totally remains 
difficult. In the era of universal immunization, HBV vaccination can be further improved in three areas: increasing global coverage, recognizing HBsAg-positive mothers with increased risk of mother-to-infant transmission, and improving responsiveness among high-risk individuals. The use of nucleoside analogues in high-risk HBsAg-positive mothers, while effective, requires long-term data of affected infants for validation, especially if universal implementation is planned. HELIPSAV can achieve high seroprotective rates in hyporesponsive individuals, and its future global availability would be crucial in the prevention of HBV among high-risk subjects.

Concerning $\mathrm{CHB}$ treatment, long-term nucleoside analogue therapy is needed to maintain permanent virologic suppression. Potential new therapies explore new methods of HBV control, including inhibiting HBsAg release, improving immunomodulation and targeting mechanisms of fibrosis. Different mechanisms of action could signify the potential for combination therapies in the future. Yet it is still uncertain if these methods could achieve HBsAg seroclearance, or more importantly, reduce and eradicate $\mathrm{HBV}$ cccDNA from infected hepatocytes. To elevate the aim of HBV therapeutics from virologic suppression to eradication, future studies on intrahepatic virologic kinetics are needed, with the focus on investigating mechanisms of intrahepatic cccDNA decline in patients achieving spontaneous or treatment-related

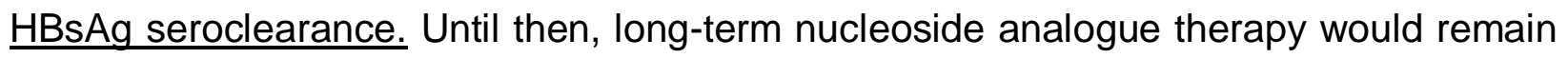
the best treatment option for $\mathrm{CHB}$. 


\section{References}

1. World Health Organization. World Health Organization Fact Sheet N²04. Published August 2008. [accessed 22 February 2012]; available from: http://www.who.int/mediacentre/factsheets/fs204/en/.

2. Lai CL, Yuen MF. Chronic hepatitis B--new goals, new treatment. N Engl J Med 2008;359:2488-2491.

3. Beasley RP, Hwang LY, Lee GC, et al. Prevention of perinatally transmitted hepatitis B virus infections with hepatitis B virus infections with hepatitis B immune globulin and hepatitis B vaccine. Lancet 1983;2:1099-1102.

4. $\mathrm{Ni} \mathrm{YH}$, Huang $\mathrm{LM}$, Chang $\mathrm{MH}$, et al. Two decades of universal hepatitis $\mathrm{B}$ vaccination in taiwan: impact and implication for future strategies. Gastroenterology 2007;132:1287-1293.

5. Yuen MF. Revisiting the natural history of chronic hepatitis B: impact of new concepts on clinical management. J Gastroenterol Hepatol 2007;22:973-976.

6. Chen DS. Hepatitis B vaccination: The key towards elimination and eradication of hepatitis B. J Hepatol 2009;50:805-816.

7. World Health Organization. World Health Organization vaccine schedule selection form. [accessed 22 February 2012]; available from: http://apps.who.int/immunization_monitoring/en/globalsummary/ScheduleResult.cfm.

8. Implementation of Newborn Hepatitis B Vaccination-Worldwide, 2006. JAMA 2009;301:29-31. 
9. Kao JH, Hsu HM, Shau WY, et al. Universal hepatitis $B$ vaccination and the decreased mortality from fulminant hepatitis in infants in Taiwan. J Pediatr 2001;139:349-352.

10. Chen HL, Chang CJ, Kong MS, et al. Pediatric fulminant hepatic failure in endemic areas of hepatitis B infection: 15 years after universal hepatitis B vaccination. Hepatology 2004;39:58-63.

11. Chang $\mathrm{MH}$, Chen $\mathrm{CJ}$, Lai MS, et al. Universal hepatitis B vaccination in Taiwan and the incidence of hepatocellular carcinoma in children. Taiwan Childhood Hepatoma Study Group. N Engl J Med 1997;336:1855-1859.

12. Lai CL, Wong BC, Yeoh EK, et al. Five-year follow-up of a prospective randomized trial of hepatitis $B$ recombinant DNA yeast vaccine vs. plasma-derived vaccine in children: immunogenicity and anamnestic responses. Hepatology 1993;18:763-767.

13. Yuen MF, Lim WL, Cheng CC, et al. Twelve-year follow-up of a prospective randomized trial of hepatitis $B$ recombinant DNA yeast vaccine versus plasma-derived vaccine without booster doses in children. Hepatology 1999;29:924-927.

14. Yuen MF, Lim WL, Chan AO, et al. 18-year follow-up study of a prospective randomized trial of hepatitis B vaccinations without booster doses in children. Clin Gastroenterol Hepatol 2004;2:941-945.

15. But DY, Lai CL, Lim WL, et al. Twenty-two years follow-up of a prospective randomized trial of hepatitis B vaccines without booster dose in children: final report. Vaccine 2008;26:6587-6591. 
16. Zanetti AR, Mariano A, Romano L, et al. Long-term immunogenicity of hepatitis $B$ vaccination and policy for booster: an Italian multicentre study. Lancet 2005;366:13791384.

17. McMahon BJ, Dentinger CM, Bruden D, et al. Antibody levels and protection after hepatitis B vaccine: results of a 22-year follow-up study and response to a booster dose. J Infect Dis 2009;200:1390-1396.

18. Poorolajal J, Mahmoodi M, Majdzadeh R, et al. Long-term protection provided by hepatitis B vaccine and need for booster dose: a meta-analysis. Vaccine 2010;28:623631.

19. Carman WF, Zanetti AR, Karayiannis P, et al. Vaccine-induced escape mutant of hepatitis B virus. Lancet 1990;336:325-329.

20. Hsu HY, Chang MH, Ni YH, et al. Survey of hepatitis B surface variant infection in children 15 years after a nationwide vaccination programme in Taiwan. Gut 2004;53:1499-1503.

21. Coleman PF. Detecting hepatitis B surface antigen mutants. Emerg Infect Dis 2006;12:198-203.

22. Chen HL, Lin LH, Hu FC, et al. Effects of Maternal Screening and Universal Immunization to Prevent Mother-To-Infant Transmission of HBV. Gastroenterology $2012 ; 142: 773-781$.

23. Andre FE. Summary of safety and efficacy data on a yeast-derived hepatitis B vaccine. Am J Med 1989;87:14S-20S. 
24. DaRoza G, Loewen A, Djurdjev O, et al. Stage of chronic kidney disease predicts seroconversion after hepatitis B immunization: earlier is better. Am $\mathrm{J}$ Kidney Dis 2003;42:1184-1192.

25. Alavian SM, Tabatabaei SV. The effect of diabetes mellitus on immunological response to hepatitis $B$ virus vaccine in individuals with chronic kidney disease: A metaanalysis of current literature. Vaccine 2010;28:3773-3777.

26. Stevens CE, Alter HJ, Taylor PE, et al. Hepatitis B vaccine in patients receiving hemodialysis. Immunogenicity and efficacy. N Engl J Med 1984;311:496-501.

27. Burdick RA, Bragg-Gresham JL, Woods JD, et al. Patterns of hepatitis B prevalence and seroconversion in hemodialysis units from three continents: The DOPPS. Kidney Int 2003;63:2222-2229.

28. Navarro JF, Teruel JL, Mateos ML, et al. Antibody level after hepatitis B vaccination in hemodialysis patients: influence of hepatitis $\mathrm{C}$ virus infection. Am $\mathrm{J}$ Nephrol 1996;16:95-97.

29. Fabrizi F, Dixit V, Martin P, et al. Meta-Analysis: The Impact of Nutritional Status on the Immune Response to Hepatitis B Virus Vaccine in Chronic Kidney Disease. Dig Dis Sci 2011.

30. Igaki $\mathrm{N}$, Nakaji $\mathrm{M}$, Moriguchi $\mathrm{R}$, et al. An outbreak of fulminant hepatitis $\mathrm{B}$ in immunocompromised hemodialysis patients. J Gastroenterol 2003;38:968-976.

31. Collier AC, Corey L, Murphy VL, et al. Antibody to human immunodeficiency virus (HIV) and suboptimal response to hepatitis B vaccination. Ann Intern Med 1988;109:101-105. 
32. Bruguera $\mathrm{M}$, Cremades $\mathrm{M}$, Salinas $\mathrm{R}$, et al. Impaired response to recombinant hepatitis B vaccine in HIV-infected persons. J Clin Gastroenterol 1992;14:27-30.

33. Cruciani M, Mengoli C, Serpelloni G, et al. Serologic response to hepatitis B vaccine with high dose and increasing number of injections in HIV infected adult patients. Vaccine 2009;27:17-22.

34. Rey D, Krantz V, Partisani M, et al. Increasing the number of hepatitis B vaccine injections augments anti-HBs response rate in HIV-infected patients. Effects on HIV-1 viral load. Vaccine 2000;18:1161-1165.

35. Mendenhall C, Roselle GA, Lybecker LA, et al. Hepatitis B vaccination. Response of alcoholic with and without liver injury. Dig Dis Sci 1988;33:263-269.

36. Lo CM, Liu CL, Chan SC, et al. Failure of hepatitis B vaccination in patients receiving lamivudine prophylaxis after liver transplantation for chronic hepatitis $\mathrm{B} . \mathrm{J}$ Hepatol 2005;43:283-287.

37. Lefebure AF, Verpooten GA, Couttenye MM, et al. Immunogenicity of a recombinant DNA hepatitis B vaccine in renal transplant patients. Vaccine 1993;11:397399.

38. Han GR, Cao MK, Zhao W, et al. A prospective and open-label study for the efficacy and safety of telbivudine in pregnancy for the prevention of perinatal transmission of hepatitis B virus infection. J Hepatol 2011;55:1215-1221.

39. Pan CQ, Han GR, Jiang HX, et al. Telbivudine Prevents Vertical Transmission from HBeAg-Positive Women With Chronic Hepatitis B. Clin Gastroenterol Hepatol 2012. 
40. Xiao XM, Li AZ, Chen X, et al. Prevention of vertical hepatitis $B$ transmission by hepatitis B immunoglobulin in the third trimester of pregnancy. Int $\mathrm{J}$ Gynaecol Obstet 2007;96:167-170.

41. Zou H, Chen Y, Duan Z, et al. Protective effect of hepatitis B vaccine combined with two-dose hepatitis B immunoglobulin on infants born to HBsAg-positive mothers. PLoS One 2011;6:e26748.

42. Choy BY, Peiris JS, Chan TM, et al. Immunogenicity of intradermal hepatitis B vaccination in renal transplant recipients. Am J Transplant 2002;2:965-969.

43. Barraclough KA, Wiggins $\mathrm{KJ}$, Hawley $\mathrm{CM}$, et al. Intradermal versus intramuscular hepatitis B vaccination in hemodialysis patients: a prospective open-label randomized controlled trial in nonresponders to primary vaccination. Am J Kidney Dis 2009;54:95103.

44. Shafran SD, Mashinter LD, Lindemulder A, et al. Poor efficacy of intradermal administration of recombinant hepatitis B virus immunization in HIV-infected individuals who fail to respond to intramuscular administration of hepatitis B virus vaccine. HIV Med 2007;8:295-299.

45. Bunupuradah T, Ananworanich J, Pancharoen C, et al. Randomized study of intradermal compared to intramuscular hepatitis B vaccination in HIV-infected children without severe immunosuppression. Vaccine 2011;29:2962-2967.

46. Chow KM, Law MC, Leung CB, et al. Antibody response to hepatitis B vaccine in end-stage renal disease patients. Nephron Clin Pract 2006;103:c89-93. 
47. Bienzle U, Gunther M, Neuhaus R, et al. Immunization with an adjuvant hepatitis B vaccine after liver transplantation for hepatitis B-related disease. Hepatology 2003;38:811-819.

48. Cruciani M, Mengoli C, Serpelloni G, et al. Granulocyte macrophage colonystimulating factor as an adjuvant for hepatitis B vaccination: a meta-analysis. Vaccine 2007;25:709-718.

49. Rottinghaus ST, Poland GA, Jacobson RM, et al. Hepatitis B DNA vaccine induces protective antibody responses in human non-responders to conventional vaccination. Vaccine 2003;21:4604-4608.

50. Yin $\mathrm{Y}, \mathrm{Wu} \mathrm{C}$, Song J, et al. DNA immunization with fusion of CTLA-4 to hepatitis B virus (HBV) core protein enhanced Th2 type responses and cleared HBV with an accelerated kinetic. PLoS One 2011;6:e22524.

51. Akbar SM, Furukawa S, Horiike N, et al. Safety and immunogenicity of hepatitis B surface antigen-pulsed dendritic cells in patients with chronic hepatitis B. J Viral Hepat 2011;18:408-414.

52. Akira S, Uematsu S, Takeuchi O. Pathogen recognition and innate immunity. Cell 2006;124:783-801.

53. Krieg AM. Therapeutic potential of Toll-like receptor 9 activation. Nat Rev Drug Discov 2006;5:471-484.

54. Kawai T, Akira S. The role of pattern-recognition receptors in innate immunity: update on Toll-like receptors. Nat Immunol 2010;11:373-384.

55. Higgins $D$, Marshall JD, Traquina $P$, et al. Immunostimulatory DNA as a vaccine adjuvant. Expert Rev Vaccines 2007;6:747-759. 
56. Barry M, Cooper C. Review of hepatitis B surface antigen-1018 ISS adjuvantcontaining vaccine safety and efficacy. Expert Opin Biol Ther 2007;7:1731-1737.

57. Halperin SA, Van Nest G, Smith B, et al. A phase I study of the safety and immunogenicity of recombinant hepatitis B surface antigen co-administered with an immunostimulatory phosphorothioate oligonucleotide adjuvant. Vaccine 2003;21:24612467.

58. Halperin SA, Dobson S, McNeil S, et al. Comparison of the safety and immunogenicity of hepatitis B virus surface antigen co-administered with an immunostimulatory phosphorothioate oligonucleotide and a licensed hepatitis $B$ vaccine in healthy young adults. Vaccine 2006;24:20-26.

59. Halperin SA, Ward B, Cooper C, et al. Comparison of safety and immunogenicity of two doses of investigational hepatitis B virus surface antigen co-administered with an immunostimulatory phosphorothioate oligodeoxyribonucleotide and three doses of a licensed hepatitis B vaccine in healthy adults 18-55 years of age. Vaccine 2012;30:2556-2563.

60. Sablan BP, Kim DJ, Barzaga NG, et al. Demonstration of safety and enhanced seroprotection against hepatitis B with investigational HBsAg-1018 ISS vaccine compared to a licensed hepatitis B vaccine. Vaccine 2012;30:2689-2696.

61. Heyward WL, Bennett S, Janssen R, et al. Immunogenicity of two doses of investigational HEPLISAV (HBsAg-1018 ISS) compared to three doses of licensed hepatitis B vaccine (ENGERIX-B) in hypo-responsive populations (abstract). Hepatology $2011 ; 54: 880 A$.

62. Madaan A. HEPLISAV (TM) Hepatitis B Vaccine. Drugs Fut 2009;34:531-535. 
63. Cooper CL, Davis HL, Morris ML, et al. CPG 7909, an immunostimulatory TLR9 agonist oligodeoxynucleotide, as adjuvant to Engerix-B HBV vaccine in healthy adults: a double-blind phase I/II study. J Clin Immunol 2004;24:693-701.

64. Angel JB, Cooper CL, Clinch J, et al. CpG increases vaccine antigen-specific cell-mediated immunity when administered with hepatitis B vaccine in HIV infection. $J$ Immune Based Ther Vaccines 2008;6:4.

65. Agnandji ST, Lell B, Soulanoudjingar SS, et al. First results of phase 3 trial of RTS,S/AS01 malaria vaccine in African children. N Engl J Med 2011;365:1863-1875.

66. Vandepapeliere $\mathrm{P}$, Horsmans $\mathrm{Y}$, Moris $\mathrm{P}$, et al. Vaccine adjuvant systems containing monophosphoryl lipid A and QS21 induce strong and persistent humoral and T cell responses against hepatitis B surface antigen in healthy adult volunteers. Vaccine 2008;26:1375-1386.

67. Surquin M, Tielemans CL, Kulcsar I, et al. Rapid, enhanced, and persistent protection of patients with renal insufficiency by $A S 02(V)$-adjuvanted hepatitis B vaccine. Kidney Int 2010;77:247-255.

68. Betancourt AA, Delgado CA, Estevez ZC, et al. Phase I clinical trial in healthy adults of a nasal vaccine candidate containing recombinant hepatitis B surface and core antigens. Int J Infect Dis 2007;11:394-401.

69. Schiott A, Larsson K, Manniche S, et al. Posintro-HBsAg, a modified ISCOM including HBsAg, induces strong cellular and humoral responses. Int $\mathrm{J}$ Pharm $2011 ; 414: 312-320$.

70. Lebre F, Borchard G, de Lima MC, et al. Progress towards a needle-free hepatitis B vaccine. Pharm Res 2011;28:986-1012. 
71. Chang TT, Lai CL, Kew Yoon S, et al. Entecavir treatment for up to 5 years in patients with hepatitis B e antigen-positive chronic hepatitis B. Hepatology 2010;51:422430.

72. Heathcote EJ, Marcellin P, Buti M, et al. Three-year efficacy and safety of tenofovir disoproxil fumarate treatment for chronic hepatitis B. Gastroenterology $2011 ; 140: 132-143$.

73. Liaw YF, Sung JJ, Chow WC, et al. Lamivudine for patients with chronic hepatitis B and advanced liver disease. N Engl J Med 2004;351:1521-1531.

74. Yuen MF, Seto WK, Chow DH, et al. Long-term lamivudine therapy reduces the risk of long-term complications of chronic hepatitis B infection even in patients without advanced disease. Antivir Ther 2007;12:1295-1303.

75. Chang TT, Liaw YF, Wu SS, et al. Long-term entecavir therapy results in the reversal of fibrosis/cirrhosis and continued histological improvement in patients with chronic hepatitis B. Hepatology 2010;52:886-893.

76. Marcellin P, Bonino F, Lau GK, et al. Sustained response of hepatitis B e antigen-negative patients 3 years after treatment with peginterferon alpha-2a. Gastroenterology 2009;136:2169-2179.

77. Wong VW, Wong GL, Yan KK, et al. Durability of peginterferon alfa-2b treatment at 5 years in patients with hepatitis B e antigen-positive chronic hepatitis B. Hepatology 2010;51:1945-1953.

78. Gish RG, Chang TT, Lai CL, et al. Loss of HBsAg antigen during treatment with entecavir or lamivudine in nucleoside-naive HBeAg-positive patients with chronic hepatitis B. J Viral Hepat 2010;17:16-22. 
79. Papatheodoridis GV, Manolakopoulos S, Touloumi G, et al. Virological suppression does not prevent the development of hepatocellular carcinoma in $\mathrm{HBeAg}$ negative chronic hepatitis B patients with cirrhosis receiving oral antiviral(s) starting with lamivudine monotherapy: results of the nationwide HEPNET. Greece cohort study. Gut $2011 ; 60: 1109-1116$.

80. Kim KH, Kim ND, Seong BL. Discovery and development of anti-HBV agents and their resistance. Molecules 2010;15:5878-5908.

81. Fung J, Lai CL, Yuen MF. LB80380: a promising new drug for the treatment of chronic hepatitis B. Expert Opin Investig Drugs 2008;17:1581-1588.

82. Choi JR, Cho DG, Roh KY, et al. A novel class of phosphonate nucleosides. 9[(1-phosphonomethoxycyclopropyl)methyl]guanine as a potent and selective anti-HBV agent. J Med Chem 2004;47:2864-2869.

83. Yuen MF, Kim J, Kim CR, et al. A randomized placebo-controlled, dose-finding study of oral LB80380 in HBeAg-positive patients with chronic hepatitis B. Antivir Ther 2006;11:977-983.

84. Yuen MF, Han KH, Um SH, et al. Antiviral activity and safety of LB80380 in hepatitis B e antigen-positive chronic hepatitis B patients with lamivudine-resistant disease. Hepatology 2010;51:767-776.

85. Lai CL, Ahn SH, Lee KS, et al. A phase Ilb study of the efficacy and safety of LB80380 versus entecavir in treatment-naive patients with chronic hepatitis B (abstract). J Hepatol 2011;54:S535. 
86. Lai CL, Ahn SH, Lee KS, et al. Week 48 analysis of a phase Ilb study of the efficacy and safety of LB80380 versus entecavir in treatment-naive patients with chronic hepatitis B (abstract). Hepatology 2011;54:1442A.

87. Schroder I, Holmgren B, Oberg M, et al. Inhibition of human and duck hepatitis B virus by 2',3'-dideoxy-3'-fluoroguanosine in vitro. Antiviral Res 1998;37:57-66.

88. Jacquard $A C$, Brunelle MN, Pichoud $C$, et al. In vitro characterization of the antihepatitis B virus activity and cross-resistance profile of 2',3'-dideoxy-3'-fluoroguanosine. Antimicrob Agents Chemother 2006;50:955-961.

89. Michalak TI, Zhang H, Churchill ND, et al. Profound antiviral effect of oral administration of MIV-210 on chronic hepadnaviral infection in a woodchuck model of hepatitis B. Antimicrob Agents Chemother 2009;53:3803-3814.

90. Wong DK, Seto WK, Fung J, et al. Effect of nucleos(t)ide analogues therapy on HBsAg, intrahepatic HBV DNA and covalently closed cirular DNA levels (abstract). Hepatol Int 2012;6:7.

91. Romero MR, Efferth T, Serrano MA, et al. Effect of artemisinin/artesunate as inhibitors of hepatitis B virus production in an "in vitro" replicative system. Antiviral Res 2005;68:75-83.

92. Su CR, Yeh SF, Liu CM, et al. Anti-HBV and cytotoxic activities of pyranocoumarin derivatives. Bioorg Med Chem 2009;17:6137-6143.

93. Dougherty AM, Guo H, Westby $\mathrm{G}$, et al. A substituted tetrahydro-tetrazolopyrimidine is a specific and novel inhibitor of hepatitis B virus surface antigen secretion. Antimicrob Agents Chemother 2007;51:4427-4437. 
94. Yu W, Goddard C, Clearfield E, et al. Design, synthesis, and biological evaluation of triazolo-pyrimidine derivatives as novel inhibitors of hepatitis B virus surface antigen (HBsAg) secretion. J Med Chem 2011;54:5660-5670.

95. Vaillant $\mathrm{A}$, Juteau JM, Lu $\mathrm{H}$, et al. Phosphorothioate oligonucleotides inhibit human immunodeficiency virus type 1 fusion by blocking gp41 core formation. Antimicrob Agents Chemother 2006;50:1393-1401.

96. Matsumura T, Hu Z, Kato T, et al. Amphipathic DNA polymers inhibit hepatitis $\mathrm{C}$ virus infection by blocking viral entry. Gastroenterology 2009;137:673-681.

97. Cardin RD, Bravo FJ, Sewell AP, et al. Amphipathic DNA polymers exhibit antiviral activity against systemic murine Cytomegalovirus infection. Virol J 2009;6:214. 98. Wu J, Meng Z, Jiang M, et al. Hepatitis B virus suppresses toll-like receptormediated innate immune responses in murine parenchymal and nonparenchymal liver cells. Hepatology 2009;49:1132-1140.

99. Al-Mahtab M, Bazinet M, Vaillant A. REP PAC: A potent HBsAg release inhibitor that elicits durable immunological control of chronic HBV infection (abstract). Hepatology 2011;54:478A.

100. Vaillant A, Al-Mahtab M, Bazinet M. REP 9AC / REP 9AC': Potent HBsAg release inhibitors that can rapidly elicit durable immunological control of infection in patients with chronic hepatitis B (abstract). Hepatol Int 2012;6:8.

101. Yuen MF, Hui CK, Cheng CC, et al. Long-term follow-up of interferon alfa treatment in Chinese patients with chronic hepatitis B infection: The effect on hepatitis B e antigen seroconversion and the development of cirrhosis-related complications. Hepatology 2001;34:139-145. 
102. Kotenko SV, Gallagher G, Baurin VV, et al. IFN-lambdas mediate antiviral protection through a distinct class II cytokine receptor complex. Nat Immunol 2003;4:6977.

103. Doyle SE, Schreckhise H, Khuu-Duong K, et al. Interleukin-29 uses a type 1 interferon-like program to promote antiviral responses in human hepatocytes. Hepatology 2006;44:896-906.

104. Witte K, Gruetz G, Volk HD, et al. Despite IFN-lambda receptor expression, blood immune cells, but not keratinocytes or melanocytes, have an impaired response to type III interferons: implications for therapeutic applications of these cytokines. Genes Immun 2009;10:702-714.

105. Kelly C, Klenerman P, Barnes E. Interferon lambdas: the next cytokine storm. Gut 2011;60:1284-1293.

106. Sheppard P, Kindsvogel W, Xu W, et al. IL-28, IL-29 and their class II cytokine receptor IL-28R. Nat Immunol 2003;4:63-68.

107. Robek MD, Boyd BS, Chisari FV. Lambda interferon inhibits hepatitis B and C virus replication. J Virol 2005;79:3851-3854.

108. Pagliaccetti NE, Robek MD. Interferon-lambda in the immune response to hepatitis B virus and hepatitis C virus. J Interferon Cytokine Res 2010;30:585-590.

109. Hong SH, Cho O, Kim K, et al. Effect of interferon-lambda on replication of hepatitis B virus in human hepatoma cells. Virus Res 2007;126:245-249.

110. Pagliaccetti NE, Chu EN, Bolen CR, et al. Lambda and alpha interferons inhibit hepatitis B virus replication through a common molecular mechanism but with different in vivo activities. Virology 2010;401:197-206. 
111. Muir AJ, Shiffman ML, Zaman A, et al. Phase $1 \mathrm{~b}$ study of pegylated interferon lambda 1 with or without ribavirin in patients with chronic genotype 1 hepatitis $C$ virus infection. Hepatology 2010;52:822-832.

112. Friedman SL. Mechanisms of hepatic fibrogenesis. Gastroenterology 2008;134:1655-1669.

113. Bradham DM, Igarashi A, Potter RL, et al. Connective tissue growth factor: a cysteine-rich mitogen secreted by human vascular endothelial cells is related to the SRC-induced immediate early gene product CEF-10. J Cell Biol 1991;114:1285-1294.

114. Gressner OA, Gressner AM. Connective tissue growth factor: a fibrogenic master switch in fibrotic liver diseases. Liver Int 2008;28:1065-1079.

115. Rachfal AW, Brigstock DR. Structural and functional properties of CCN proteins. Vitam Horm 2005;70:69-103.

116. Chen CC, Lau LF. Functions and mechanisms of action of CCN matricellular proteins. Int J Biochem Cell Biol 2009;41:771-783.

117. Weng HL, Ciuclan L, Liu Y, et al. Profibrogenic transforming growth factorbeta/activin receptor-like kinase 5 signaling via connective tissue growth factor expression in hepatocytes. Hepatology 2007;46:1257-1270.

118. Martin-Vilchez S, Sanz-Cameno P, Rodriguez-Munoz Y, et al. The hepatitis B virus $\mathrm{X}$ protein induces paracrine activation of human hepatic stellate cells. Hepatology 2008;47:1872-1883.

119. Brigstock DR. Strategies for blocking the fibrogenic actions of connective tissue growth factor (CCN2): From pharmacological inhibition in vitro to targeted siRNA therapy in vivo. J Cell Commun Signal 2009;3:5-18. 
120. Wang Q, Usinger W, Nichols B, et al. Cooperative interaction of CTGF and TGFbeta in animal models of fibrotic disease. Fibrogenesis Tissue Repair 2011;4:4.

121. Dimou AT, Syrigos KN, Saif MW. Novel agents in the management of pancreatic adenocarcinoma: phase I studies. Highlights from the "2011 ASCO Gastrointestinal Cancers Symposium". San Francisco, CA, USA. January 20-22, 2011. JOP 2011;12:114-116.

122. Adler SG, Schwartz S, Williams ME, et al. Phase 1 study of anti-CTGF monoclonal antibody in patients with diabetes and microalbuminuria. Clin J Am Soc Nephrol 2010;5:1420-1428.

123. Maini MK, Schurich A. The molecular basis of the failed immune response in chronic HBV: therapeutic implications. J Hepatol 2010;52:616-619.

124. Michel ML, Deng Q, Mancini-Bourgine M. Therapeutic vaccines and immunebased therapies for the treatment of chronic hepatitis B: perspectives and challenges. $\mathrm{J}$ Hepatol 2011;54:1286-1296.

125. Xu DZ, Zhao K, Guo LM, et al. A randomized controlled phase Ilb trial of antigenantibody immunogenic complex therapeutic vaccine in chronic hepatitis B patients. PLoS One 2008;3:e2565.

126. Wang $X Y$, Zhang $X X$, Yao $X$, et al. Serum HBeAg sero-conversion correlated with decrease of HBsAg and HBV DNA in chronic hepatitis B patients treated with a therapeutic vaccine. Vaccine 2010;28:8169-8174.

127. Mancini-Bourgine M, Fontaine H, Scott-Algara D, et al. Induction or expansion of T-cell responses by a hepatitis B DNA vaccine administered to chronic HBV carriers. Hepatology 2004;40:874-882. 
128. Mancini-Bourgine $\mathrm{M}$, Fontaine $\mathrm{H}$, Brechot $\mathrm{C}$, et al. Immunogenicity of a hepatitis B DNA vaccine administered to chronic HBV carriers. Vaccine 2006;24:4482-4489.

129. Rigopoulou El, Suri D, Chokshi S, et al. Lamivudine plus interleukin-12 combination therapy in chronic hepatitis B: antiviral and immunological activity. Hepatology 2005;42:1028-1036.

130. Fontaine $\mathrm{H}$, Chazallon $\mathrm{C}$, Mancini-Bourgine $\mathrm{M}$, et al. Relapse after analogues treatment discontinuation is not prevented by DNA vaccination in chronic hepatitis $B$ (abstract). Hepatology 2011;54:1064A.

131. Spellman M, Martin JT. Treatment of chronic hepatitis B infection wi th DV-601, a therapeutic vaccine (abstract). J Hepatol 2011;54:S302. 


\section{Figure legends}

Figure 1. The molecular structure of besifovir (LB-80380), and its two metabolites LB80331 and LB-80317.

Figure 2. The molecular structure of interferon-lambda.

Figure 3. The 4 domains of connective tissue growth factor (CTGF), with the second domain being the binding site of FG-3019. 

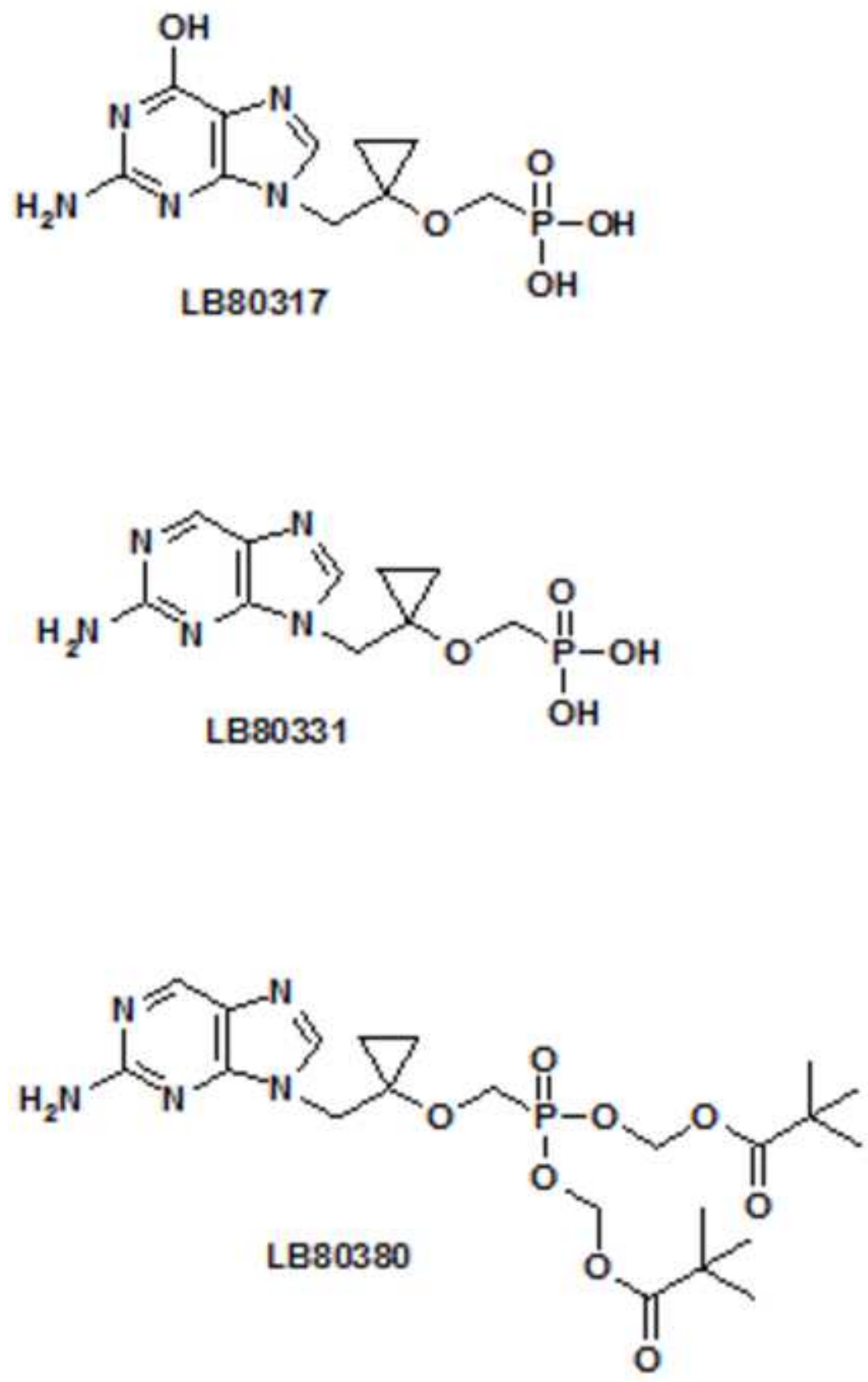


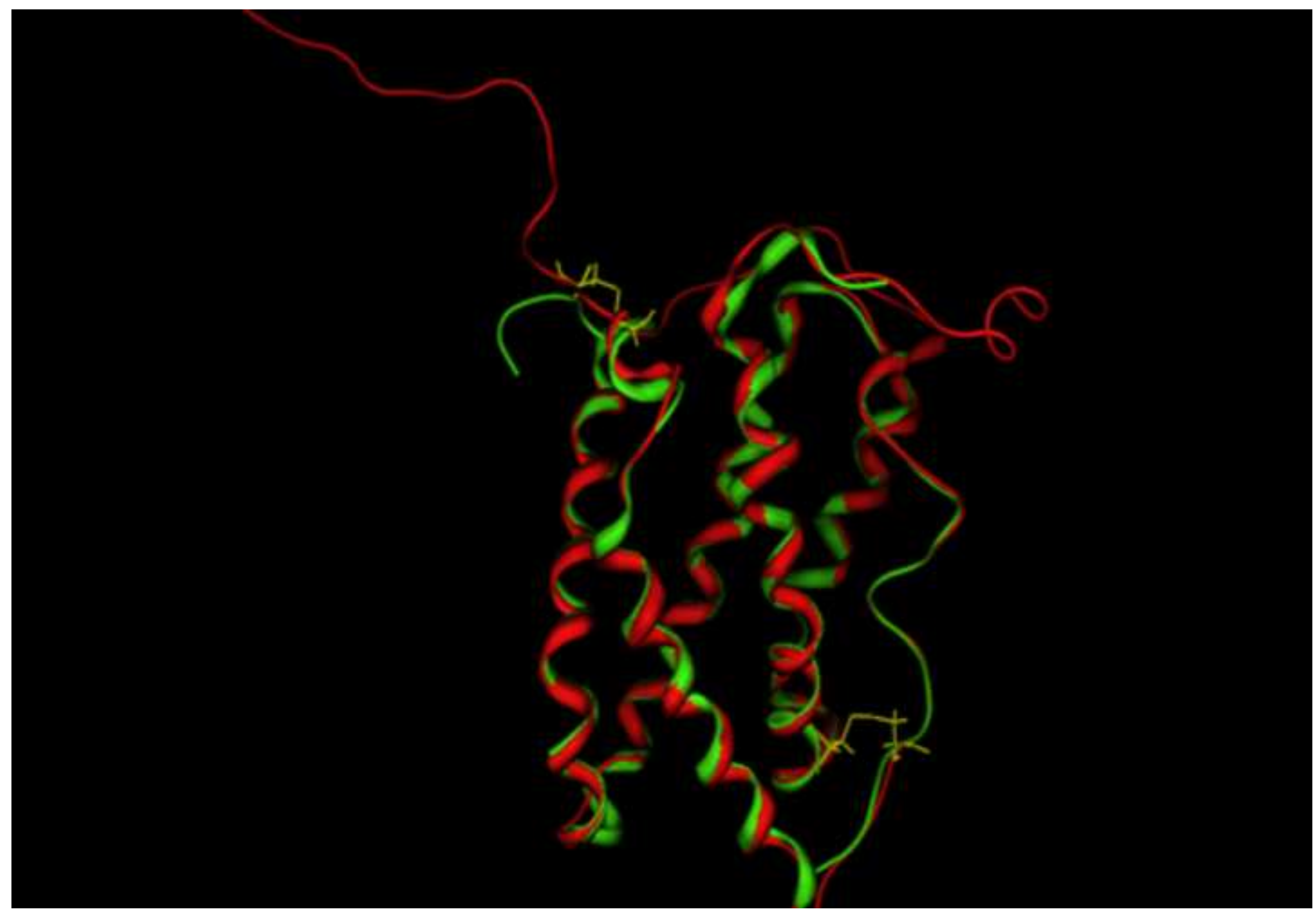




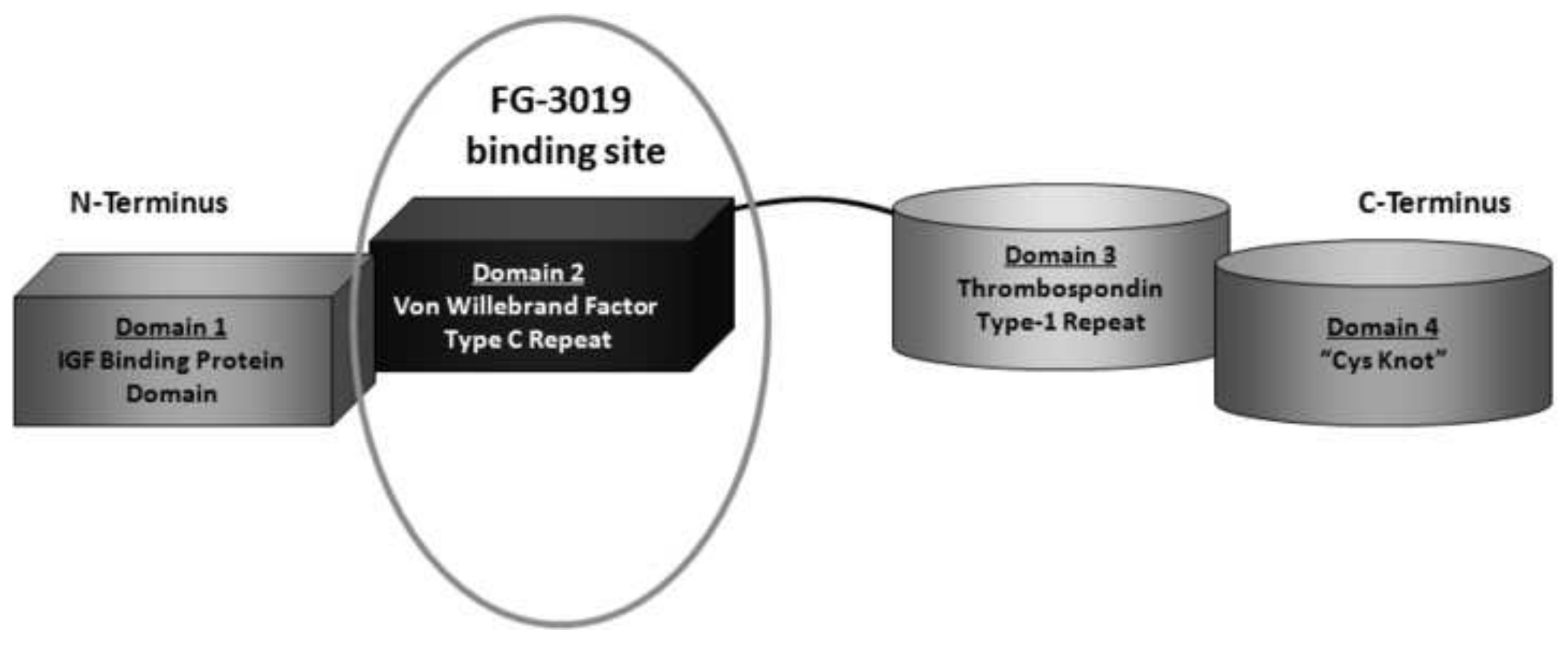


Table 1. Factors associated with HBV vaccination failure

\begin{tabular}{|c|c|c|}
\hline Subjects & Factors & $\begin{array}{l}\text { Methods to improve vaccine } \\
\text { response }\end{array}$ \\
\hline Newborn & $\begin{array}{l}\text { HBsAg-positive mothers (especially } \\
\text { HBeAg-positive) } \\
\text { Mothers with high viral load }\end{array}$ & $\begin{array}{l}\text { - } \mathrm{HBsAg} / \mathrm{HBeAg} \\
\text { screening } \\
\text { - Nucleoside analogue } \\
\text { therapy for high-risk } \\
\text { mothers } \\
\text { - HBIG for high-risk } \\
\text { mothers / infants }\end{array}$ \\
\hline Adult & $\begin{array}{l}\text { Increasing age } \\
\text { Obesity } \\
\text { Smoking } \\
\text { Diabetes } \\
\text { End-stage renal disease } \\
\text { HIV infection } \\
\text { Alcoholics with overt liver disease } \\
\text { Recipients of liver / kidney } \\
\text { transplantation }\end{array}$ & $\begin{array}{l}\text { - ISS-based vaccination } \\
\text { (e.g. HELIPSAV) } \\
\text { - Intradermal vaccination } \\
\text { - Increasing vaccination } \\
\text { dose } \\
\text { - Improving vaccine } \\
\text { adjuvant formula } \\
\text { - Using plasmid DNA } \\
\text { vaccines } \\
\text { - Using HBsAg-pulsed } \\
\text { dendritic cells }\end{array}$ \\
\hline
\end{tabular}

$\mathrm{HBV}$, hepatitis B virus; $\mathrm{HBsAg}$, hepatitis $B$ surface antigen; $\mathrm{HBeAg}$, hepatitis $\mathrm{B}$ e antigen; HBIG, hepatitis B immunoglobulin; ISS, immunostimulatory DNA sequences; HIV, human immunodeficiency virus. 
Table 2. Promising HBV vaccine adjuvants undergoing clinical trials in human subjects

\begin{tabular}{|c|c|c|c|}
\hline & & $\begin{array}{l}\text { Stage of } \\
\text { research }\end{array}$ & Efficacy \\
\hline HELIPSAV & $\begin{array}{l}\text { Immunostimulatory } \\
\text { CpG }\end{array}$ & Phase III & $\begin{array}{l}\text { Effective in normal and } \\
\text { hyporesponsive subjects }\end{array}$ \\
\hline CPG 7909 & $\begin{array}{l}\text { Immunostimulatory } \\
\text { CpG }\end{array}$ & Phase II & $\begin{array}{l}\text { Effective in HIV-infected } \\
\text { individuals }\end{array}$ \\
\hline AS02 & $\begin{array}{c}\text { Monophosphoryl lipid } \\
\text { A and QS } 21\end{array}$ & Phase II & $\begin{array}{l}\text { Effective in patients with } \\
\text { renal insufficiency }\end{array}$ \\
\hline $\begin{array}{l}\text { Plasmid DNA } \\
\text { pWRG7128 }\end{array}$ & $\begin{array}{l}\text { DNA vaccine taken } \\
\text { orally }\end{array}$ & Phase I & $\begin{array}{c}\text { Humoral and cell-mediated } \\
\text { responses induced in } \\
\text { hyporesponsive subjects }\end{array}$ \\
\hline NASVAC & $\begin{array}{l}\text { Recombinant } \mathrm{HBsAg} \\
\text { and } \mathrm{HBcAg} \text { taken } \\
\text { intranasally }\end{array}$ & Phase I & Seroprotective up to 90 days \\
\hline
\end{tabular}

CpG, cytosine phosphoguanosine; QS, Quillaja saponaria; HBsAg, hepatitis B surface antigen; HBcAg, hepatitis B core antigen 
Table 3. Promising therapeutic options for chronic hepatitis B

\begin{tabular}{|c|c|c|c|}
\hline Drug & Category & $\begin{array}{l}\text { Phase of } \\
\text { clinical trial }\end{array}$ & Preliminary results \\
\hline Besifovir & $\begin{array}{l}\text { Nucleotide } \\
\text { analogue }\end{array}$ & Phase II & $\begin{array}{l}\text { High rates of virologic } \\
\text { suppression in both } \\
\text { treatment-naïve and } \\
\text { lamivudine-resistant CHB }\end{array}$ \\
\hline Lagociclovir & $\begin{array}{l}\text { Nucleoside } \\
\text { analogue }\end{array}$ & Phase I & $\begin{array}{l}\text { Significant reduction in } \\
\text { cccDNA in woodchuck model }\end{array}$ \\
\hline REP 9AC & $\begin{array}{l}\text { HBsAg release } \\
\text { inhibitor }\end{array}$ & Phase II & $\begin{array}{l}\text { Significant serum HBsAg } \\
\text { reduction }\end{array}$ \\
\hline Interferon- $\lambda$ & Interferon & Phase II & $\begin{array}{l}\text { Inhibit HBV replication in } \\
\text { animal studies }\end{array}$ \\
\hline FG-3019 & $\begin{array}{l}\text { Connective tissue } \\
\text { growth factor }\end{array}$ & Phase II & $\begin{array}{l}\text { Reduces liver fibrosis in } \\
\text { animal studies }\end{array}$ \\
\hline DV-601 & $\begin{array}{l}\text { Therapeutic } \\
\text { vaccine }\end{array}$ & Phase I & $\begin{array}{l}\text { Significant reductions in } \\
\text { serum HBV DNA, HBsAg and } \\
\text { HBeAg }\end{array}$ \\
\hline
\end{tabular}

